\title{
Evaluation of Germplasm for Different Physicochemical Characteristics and Antioxidant Compounds of Strawberry Fruits
}

\author{
KK Pramanick ${ }^{1 *}$, Surabhi Sharma ${ }^{1}$, Neerja Rana ${ }^{2}$ and Dhiren Gupta ${ }^{1}$ \\ ${ }^{1}$ Department of Regional Station Cereals \& Hoticultural Crops, Indian Agricultural Research Institute, India \\ ${ }^{2}$ Department of Basic Sciences Biochemistry, Dr. Y. S. Parmar University of Horticulture and Forestry, India
}

Submission: November 21, 2017; Published: December 11, 2017

"Corresponding author: KK Pramanick, Department of Regional Station (Cereals \& Hoticultural Crops), Indian Agricultural Research Institute, Amartara Cottage, Cart Road,Shimla-171004 (H.P.) India, Tel: 0177-2655305; Fax: 2808766; Email: kallolpramanick@gmail.com/kallol_ pramanick@yahoo.co.in

\begin{abstract}
Strawberry fruit contains vitamins and antioxidant compounds. These dietary antioxidants have been known for its different health promoting benefits. The objective of the research was to evaluate quality parameters of ten strawberry genotypes namely Pusa Early Dwarf, Chandler, Red Guart, Cat Skill, IC-319114, EC-431388, IC-319105, IC-319134, IC-319129 and IC-319130. The following parameters were determined in the harvested fruits: total soluble solids (TSS), total acidity (TA), TSS/TA ratio, total anthocyanins, total phenolics (TP), total carotenoids and amino acids. The genotypes: Pusa Early Dwarf, Red Guart, IC-319129 and EC-431388 had significantly higher total soluble solids, anthocyanins and other antioxidant compounds. This study showed the important of genetic background on the chemical and antioxidant profiles of strawberry fruits.
\end{abstract}

Keywords: Fruit; Strawberry cultivars; Nutritional quality; Antioxidant compounds

\section{Introduction}

Strawberry is a non-climacteric fruit, so are harvested at ripe stage. The fruit of strawberry has attractive color, desirable taste and is also a good source of carbohydrates, vitamins and antioxidants compounds like phenols, carotenoids and anthocyanins. These antioxidant compounds present in berries have known to lower the risk of many diseases Wang \& Jiao [1], Milivojevic et al. [2].

The quality characteristics can be sensory or nutritional. This is also dependent on physical or chemical characteristics for the determination of optimum maturity that changes in the selected parameters correlating with the attainment of the general composition of quality characteristics of the product [3]. Parameters like total acids (TA), total soluble solids (TSS) and their ratio (TSS/TA) are very important in determining fruit quality $[3,4]$, as it determine the flavour harmony along with color. Sugar and acids content vary from 4.66-8.43 percent and $0.56-1$ percent respectively [5]. Sugars are also considered as the main non-volatile flavor compound [6].

Other parameters of significance include amino acids, total phenols, carotenoids and anthocyanins. The polyphenols are significant as they have a positive effect on human health [7]. Anthocyanins are the natural pigments responsible for a wide range of red fruits [8]. The total anthocyanins content in strawberry fruits can vary from $150-600 \mathrm{mg} / \mathrm{kg}$ fresh weight. The antioxidant capacity in berries seems to be mostly due to the activity of phenolics compounds, such as anthocyanins and vitamins. The total phenolics content varies from 0.4 up to $3 \mathrm{mg}$ /1 g [9-11].

This study has been designed to investigate the physicochemical characteristics and antioxidant compounds of strawberry fruit like weight, size, shape index, total soluble solids (TSS), total acidity (TA), TSS/TA ratio, total phenolics (TP), carotenoids and anthocyanins in selected strawberry genotypes.

\section{Materials and Methods}

Ten strawberry (Fragaria×ananassa) genotypes (IC319114, EC-431388, Pusa Early Dwarf, Chandler, IC-319105, IC319134, IC-319129, Red Guart, Cat Skill, IC-319130) grown in an open field condition were used in investigation. Fruits were harvest at full maturity (full red color). The fruit samples were analyzed immediately after harvest. The fruits were mashed 
in a homogenizer and prepared for further analysis. Three replications were used per analysis.

\section{Physicochemical Characteristics}

Fresh weight of fruits was measured using electronic balance and length and width of fruits were measured by a digital caliper.

Total soluble solids (TSS), expressed in Bricks, were measured using digital refractometer.

Total acidity (TA) was measured according to the AC method given by Ranganna [12] and expressed in percentage of citric acid.

\section{Total Phenolics}

The amounts of total phenolics in the fruits were determined with the Folin-Ciocalteu reagent according to the method of Bray \& Thorpe [13] using catechol as a standard. One gram of sample was taken and grinded with $10 \mathrm{ml}$ of 80 per cent ethanol in pestle and mortar, and centrifuged for $20 \mathrm{~min}$ at $1000 \mathrm{rpm}$ and filtered. Filtrate was evaporated in oven up to dryness and dried extract was dissolved in $5 \mathrm{ml}$ distilled water. $0.2-2.0 \mathrm{ml}$ aliquot was taken in separate test tubes and volume was made up to $3 \mathrm{ml}$. Then, $0.5 \mathrm{ml}$ Folin-Ciocalteu reagent was added. After $3 \mathrm{~min} 2 \mathrm{ml}$ of $\mathrm{Na} 2 \mathrm{CO} 3(20 \%)$ was added and mixed. Test tubes were placed in boiling water bath for one min and then cooled. Optical density of the sample was recorded at $650 \mathrm{~nm}$ with the help of Spectronic-20. The concentration was determined as per the standard procedure from the standard curve. The standard curve was prepared using different concentrations $(8-32 \mu \mathrm{g} / \mathrm{ml})$ of catechol and results were expressed as mg per $100 \mathrm{~g}$ on fresh weight basis.

\section{Total Carotenoids}

A known weight of sample was macerated with acetone in pestle and mortar and extract was decanted into a conical flask. Extraction was continued till the residue became colorless. All extracts were combined and transferred into a separating funnel. $10-15 \mathrm{ml}$ of petroleum ether was added to transfer the red pigments into the petroleum ether and 5\% sodium sulphate was added to it. Again petroleum ether was added to transfer all color into it and then separated out from separating funnel into $50 \mathrm{ml}$ volumetric flask and volume was made up to $25 \mathrm{ml}$ by petroleum ether. The color intensity (optical density) was measured in Spectronic-20 at $452 \mathrm{~nm}$ using 3\% acetone in petroleum ether as blank. The results were expressed in terms of $\beta$-carotene as $\mathrm{mg} / 100 \mathrm{~g}$ of the sample [12].

$\beta$-carotene $(\mathrm{mg} / 100 \mathrm{~g})=\frac{\mu \text { gof carotene per } \mathrm{ml} \times \text { dilution } \times 100 \text { as read from curve }}{\text { Weight of sample } \times 1000}$

\section{Total Anthocyanins}

The blended sample $(10 \mathrm{~g})$ was mixed with $10 \mathrm{ml}$ of ethanolhydrochloric acid mixture $(95 \% \mathrm{C} 2 \mathrm{H} 5 \mathrm{OH}$ and $1.5 \mathrm{~N} \mathrm{HCI}$ in the ratio of $85: 15)$, transferred into a $100 \mathrm{ml}$ volumetric flask, kept overnight at $4{ }^{\circ} \mathrm{C}$, filtered through What man No. 1 and eventually optical density of filtrate was measured at $535 \mathrm{~nm}$ in a spectrophotometer. Total anthocyanins content was expressed as mg 100g-1 fruit weight [14].

\section{Results}

Fresh fruit weight, length, width and shape index of strawberry fruits were significantly different among different genotypes. The fruit weight ranged between 4.01 to $10.03 \mathrm{~g}$ however, maximum weight was found in IC-319130 (10.03g) followed by Pusa Early Dwarf (7.15g) and Cat Skill (6.87g). The fruit shape of Cat Skill, Pusa Early Dwarf, Chandler, IC-319134 and IC-319130 was conical showing an index of length to width of 1.47-1.72, where as that of IC-31914, IC-319129 and Red Guart was cordite with a ratio nearly 1.3.

Pusa Early Dwarf had the maximum total soluble solids $\left(10.6^{\circ} \mathrm{B}\right)$. However, TSS in all the genotypes ranged from $7.2^{\circ}$ B to $10.6^{\circ}$ B. The total acid was minimum in Catskill (3.9g/l) expressed as citric acid. The relationship between total soluble solids and total acidity is very important in fruit quality because it provides information on the balance of sugars and acids in the fruit (Figure 1).

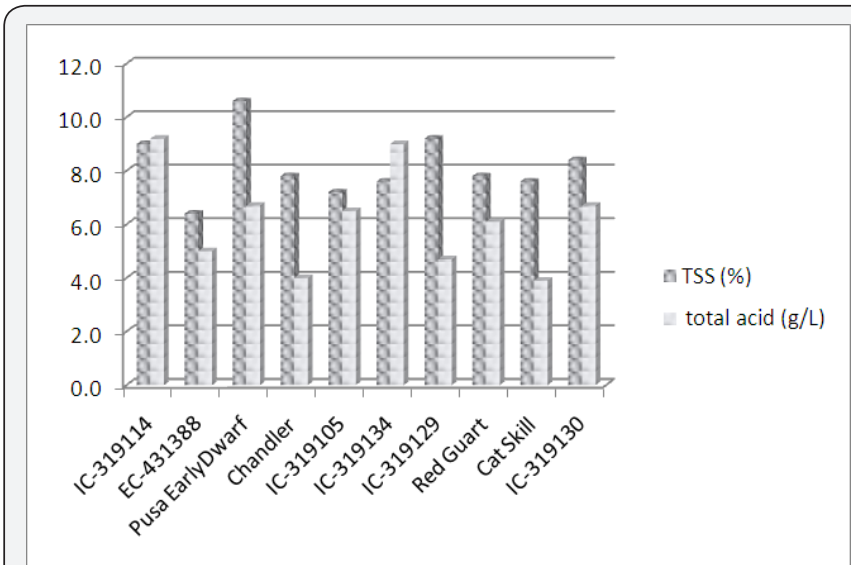

Figure 1: Total soluble solid and total acid of ten selected strawberry genotypes.

Total phenols, anthocyanins and amino acid in selected strawberry germplasm is given in (Figure 2). The total phenols ranged from $90 \mathrm{mg} / 100 \mathrm{~g}$ (Red Guart) to $420 \mathrm{mg} / 100 \mathrm{~g}$ (IC319114). Besides size and shape, color is another important component of strawberry fruit appearance and it is defined by pigments like anthocyanins and carotenoids. The total amino acids estimated is given in Figure 2. The amino acid content was maximum $270 \mathrm{mg} / 100 \mathrm{~g}$ in IC-319114, EC-431388 and IC-319134 followed by Pusa Early Dwarf and Red Guart (250mg/100g). The anthocyanins content was maximum in IC-319129 (100mg/100g), followed by EC-431388 $(99 \mathrm{mg} / \mathrm{kg})$. However the carotenoids content was recorder maximum $13.50 \mathrm{mg} / 100 \mathrm{~g}$ in IC-319129 and minimum was recorded $4.50 \mathrm{mg} / 100 \mathrm{~g}$ in IC319134 in genotypes on fresh weight basis (Figure 3). 


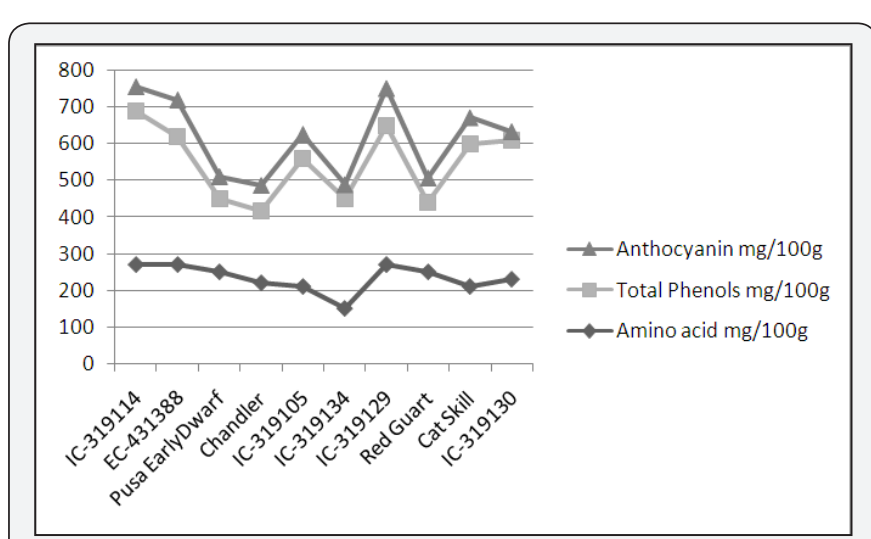

Figure 2: Antioxidant compounds of diffrent strawberry genotypes.

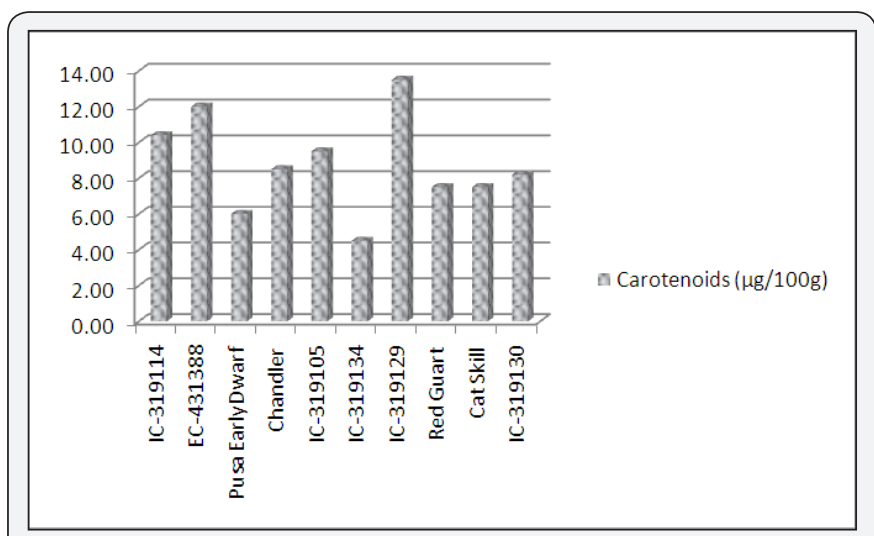

Figure 3: Carotenoid content of different strawberry genotypes.

\section{Discussion}

The quality of a cultivar depends on different parameters, which when united gives an integral picture of selected fruits. The average weight of the fruits ranged from $4.01 \mathrm{~g}$ to $10.03 \mathrm{~g}$, with Red Guart being the smallest and IC-319130 the largest. The development was affected by numerous factors including the numbers and development of achenes on the receptacle [15]. The fruit shape of cultivars was conical and cordite. Kim et al. [16] mentioned that fruit shapes were the major characteristic for the classification of cultivar. The shape was affected by the numbers of achenes pollinated, temperature at time of planting or during fruit set and plant nutrition [17-19].

Pusa Early Dwarf had the highest total soluble solid content $\left(10.6^{\circ} \mathrm{B}\right)$ according the Vocal et al. 2008 the TSS of different cultivar ranged from 6.00 to $10.01^{\circ}$ B., while Lau gale \& Blite [20] reported values from 8.4 to $11.6 \%$ depending on the cultivar. Strawberry flavour is conditioned in part by the balance between sugar and acids expressed in ripe fruits and the organic acids are the second contributor (after sugar) to the soluble solids of strawberries [21]. Citric acid contributes $92 \%$ and malic acid $9 \%$ of acidity. Total acidity values ranged from $3.9 \mathrm{~g} / \mathrm{l}$ to $9.2 \mathrm{~g} / \mathrm{l}$, in numerous researches conducted on different strawberry cultivars TSS/TA ratio was found to be very important because it provides information on the balance of sugars and acids in the fruit. For this reason along with fruit color, this was until recently considered to be the main parameter for determining fruit quality [22].

There were significant differences in anthocyanins content among cultivar (Figure 1). Kim et al. [23] reported the anthocyanins content of strawberry cultivars at red stage ranged from $38.3-60.8 \mathrm{mg} / 100 \mathrm{~g}$ of fw. Pelayo et al. [24] reported that distribution of anthocyanins pigment in fruit tissues of different strawberry cultivars is not uniform. The total carotenoids in all the cultivars analyzed ranged from $15.50 \mathrm{mg} / 100$ to $4.50 \mathrm{mg} / 100$.

\section{Conclusion}

The genotypes Pusa Early Dwarf, Red Guart, IC-319129 and EC-431388 were found to be prospective as they possessed a higher content of total soluble solids, anthocyanins content and antioxidants. The cultivars have high antioxidant compounds beneficial for human health. This study showed the important of genetic background on the chemical and antioxidant profiles of strawberry fruits which could be used directly or used in breeding programmes for further improvement.

\section{References}

1. Wang SY, Jiao H (2000) Scavenging capacity of berry crops on superoxide radicals, hydrogen peroxide, hydroxyl radicals and singlet oxygen. J Agric Food Chem 48: 5677-5684.

2. Milivojeviš J, Maksimoviš V, Nikoliš $\mathrm{M}$, Bogdanoviš J, Maletiš $\mathrm{R}$, et al. (2011) Chemical and antioxidant properties of cultivated and wild Fragaria and Rubus berries. J Food Qual 34: 1-9.

3. Sturm K, Koron D, Stampar F (2003) The composition of different strawberry varieties depending on maturity stage. Food Chem 83: 417422.

4. Testoni A, Lovati F , Nuzzi M (2006) Evaluation of post harvest quality of strawberries. Acta Hortic Italy 708: 355-358.

5. Šoškiš M (2009) Jagoda. Partenon, Beograd. pp. 14-15.

6. Blood KC, Zabetakis I (2002) The biosynthesis of strawberry flavor (II): Biosynthetic and molecular biology studies. J Food Sci 67: 2-8.

7. Gill MI, Folcroft DM, Kader AA (1997). Changes in strawberry anthocyanins and other polyphenols in response to carbon dioxide treatments. J Agric Food Chem 45: 1662-1667.

8. Lopes da, Silva F, Escribano-Bailón MT, Péres Alonso JJ, Rivas-Gonzalo JC et al. (2007) Anthocyanin pigments in strawberry. LWT. 40: 374-382.

9. Heinonen IM, Meyer AS, Frankel EN (1998) Antioxidant activity of berry phenolics on human low-density lipoprotein and liposome oxidation. J Agric Food Chem. 46: 4107-4112.

10. Kalt W, Forney CF, Martin A, Prior RL (1999) Antioxidant capacity, vitamin $\mathrm{C}$, phenolics, and anthocyanins after fresh storage of small fruits. J Agric Food Chem. 47: 4638-4644.

11. Häkkinen SH, Kärenlampi SO, Mykkänen HM, Heinonen IM, Törrönen AR (2000) Ellagic acid content in berries: Influence of domestic processing and storage. Eur. Food Res. Technol. 212: 75-80.

12. Ranganna S (1986) Handbook of analysis and quality control for fruit and vegetable products. ( $2^{\text {nd }}$ edn), McGrawHill, New Dehli, India, pp. 976-979. 
13. Bray HG, Thorpe WV (1954) Standard methods of biochemical analysis. Kalyani Publishers, New Delhi, India.

14. Harborne JB (1973) Phytochemical Methods. Toppan Co. Ltd, Tokyo, Japan.

15. Moore JN, Brown GR, Brown ED (1970) Comparison off actors influencing fruit size in large-fruited and small-fruited clones of strawberry. J Amer Soc Hort Sci 95: 827-831.

16. Kim DY, Yoon MK, Kwak JH, Kim TI, Kim JH (2009) Classification of strawberry germplasms based on horticultural traits and principal component analysis. Kor J Hort Sci Technol 27: 636-643.

17. Albregts EE, Howard CM (1982) Effect of fertilizer rate on number of malformed strawberry fruit. Proc Fla State Hort Soc 95: 323-324.

18. Dana MN (1980) The strawberry plant and its environment. Childers NF (Ed.), The strawberry: Varieties, culture, pests and control, storage, marketing. Horticultural Publications Gainesville FL pp. 33-44.

19. Darrow GM (1966) The strawberry Holt, Rinehart \& Winston, NewYork, USA.

20. Laugale V, Bite A (2006) Fresh and processing quality of different strawberry cultivars for Latvia. Acta Hortic. 708: 333-336.
21. Cordenunsi BR, Roberto JO, Nascimento OD, Ineä M, Genovese S, et al. (2002) Influence of Cultivar on Quality Parameters and Chemical Composition of Strawberry Fruits Grown in Brazil. Agric Food Chem 50: 2581-2586

22. Green A (1997) The Biochemistry of Fruits and their Products. In: Hulme AC (Ed.), Academic Press, London, UK, 2: 375-410.

23. Kim SK, Bae RN, Haeyoung N, Ko KD, Chun C (2013) Changes in Physicochemical Characteristics during Fruit Development in Junebearing Strawberry Cultivars. Hort Environ Biotechnol 54(1): 44-51.

24. Pelayo C, Ebeler SE, Kader AA (2003) Postharvest life and flavor quality of three strawberry cultivars kept at $5{ }^{\circ} \mathrm{C}$ in air orair $+20 \mathrm{kPa} \mathrm{CO}_{2}$ Postharvest Biol Technol 27: 171-183.

25. Clifford MN (2000) Anthocyanins: nature, occurrence and dietary burden. J Sci Food Agric 80: 1063-1072.

26. Kosar M, Kafkas E, Paydas S, Baser K (2004) Phenolic composition of strawberry genotypes at different maturation stages. J Agric Food Chem. 52: 1586-1589.

Your next submission with Juniper Publishers will reach you the below assets

- Quality Editorial service

- Swift Peer Review

- Reprints availability

- E-prints Service

- Manuscript Podcast for convenient understanding

- Global attainment for your research

- Manuscript accessibility in different formats

( Pdf, E-pub, Full Text, Audio)

- Unceasing customer service

Track the below URL for one-step submission https://juniperpublishers.com/online-submission.php 